Click www.researchjournal.co.in/online/subdetail.html to purchase.

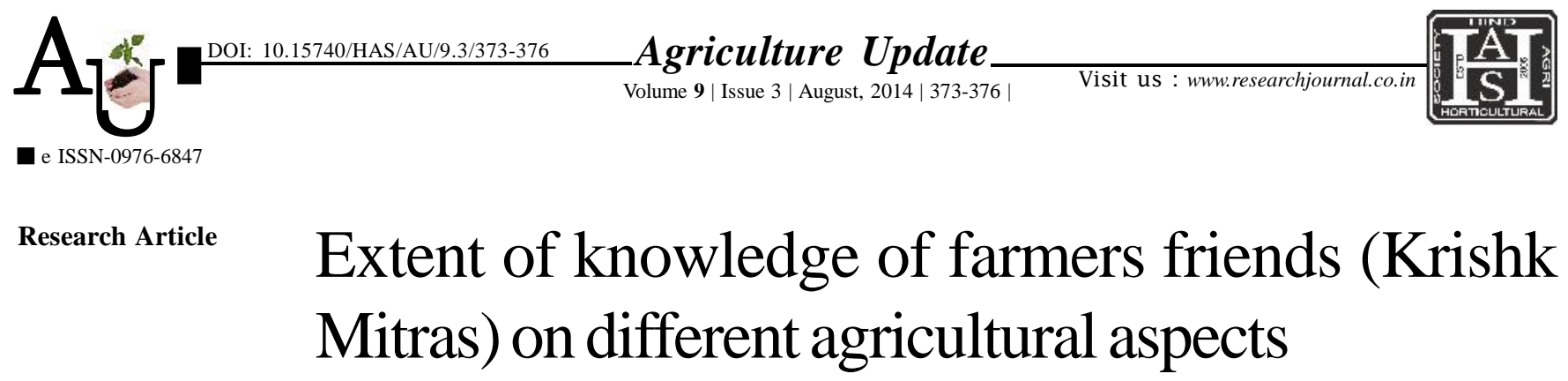

D.S. BHATI, B.S. SIDHU, SEEMA JASUJA, J.R. VERMA AND A.K. SRIVASTAVA

Article Chronicle： Summary : Farmers friends work as the village level extension worker under ATMA in each and every district Received : 28.05.2012;

Revised :

22.06.2014;

Accepted :

04.07.2014

of the Rajasthan. They face various problems related to the different aspect agriculture; hence, government of Rajasthan decided to trained the farmers friends through Krishi Vigyan Kendra of the district. The study was conducted on 1000 farmers friends of the Sriganganagar district of Rajasthan. The findings of this study highlighted that there was a significant gain in the knowledge about different aspect of agriculture included in the training programme. The correlation between knowledge of agricultural aspect and socio-personnel characteristics of trainees also showed that caste, education, occupation, mass media exposure, contact with extension agent and annual income were positively where as age, type of family and size of holding were negatively correlated.

How to cite this article : Bhati, D.S., Sidhu, B.S., Jasuja, Seema, Verma, J.R. and Srivastava, A.K. (2014). Extent of knowledge of farmers friends (Krishk Mitras) on different agricultural aspects. Agric. Update, 9(3): 373-376.

KeY Words:

Farmers friends, Extent of knowledge, Agriculture training programme

Author for correspondence :

\title{
D.S. BHATI
}

Krishi Vigyan Kendra, SRIGANGANAGAR (RAJASTHAN) INDIA

Email: dsbhati06@ rediffmail.com

See end of the article for authors' affiliations 